\title{
Can owners afford humanitarian donations in agbiotech - The case of genetically engineered eggplant in India
}

\author{
Deepthi Kolady* \\ Department of Applied Economics and Management \\ Cornell University \\ Ithaca, New York, USA 14853 \\ Tel: 6072558048 \\ Fax: 6072559984 \\ E-mail: dek28@cornell.edu \\ William Lesser \\ Susan Eckert Lynch Professor in Science and Business \\ Department of Applied Economics and Management \\ Cornell University \\ Ithaca, New York, USA, 14853 \\ Tel: 6072554595 \\ Fax: 6072559984 \\ E-mail: whl1@cornell.edu \\ Website: www.cornell.edu
}

Financial support: Ford Foundation International Fellowships program and USAID funded ABSPII project provided financial support for the research.

Keywords: Bt eggplant, market segmentation, public-private partnership.

Abbreviations: Bt: Bacillus thuringiensis

$\mathrm{CV}$ : contingent valuation

GE: genetically engineered

OPV: open pollinated variety

OPVS: open pollinated varieties

WTP: willingness to pay

\begin{abstract}
Are humanitarian donations in agbiotech economically feasible for the donor? We address this question by conducting an ex ante analysis of genetically engineered (GE) eggplant in India. Our analysis indicates that it is economically viable for a firm to donate the technology for poor farmers' use by restricting use to open pollinated varieties while selling hybrid verities. By extension, this means of segmenting markets would likely apply in cases where different levels of production technologies are used based on access to market, irrigation, and credit, at least for perishable crops.
\end{abstract}

Facilitating access for the poor to new products and technologies has received considerable attention in recent years. Much has been focused on pharmaceuticals and AIDS drugs in particular, contributing to such changes as agreements by major firms to sell drugs at cost in developing countries and to investments by the Gates Foundation and others for developing pharmaceuticals focused on diseases of tropical countries, like malaria. Similar concerns over access have been expressed for agricultural technologies, with particular scrutiny of biotechnology. To date, small cotton farmers in India and China have been able to adopt those products at market prices, but the situation for food crops for home and local consumption may be quite different from cash commodity crops like cotton.

The costs of developing the novel traits and, particularly, satisfying national human and environmental safety regulations has meant the majority of the investment worldwide in these new products has been made by the private sector (except in China), a complete change from the public sector-driven Green Revolution (FAO, 2004). Private sector firms nonetheless have expressed a willingness to make full and partial donations of technologies for small farmer use. For example, the public sector may be able to negotiate non-exclusive licenses for use of the proprietary technologies at no or low cost in markets that are not of interest to the private sector. Such efforts have included full donations, such as all developing country farmers (Byerlee and Fischer, 2002). However, such gifts place a significant cost burden on the public sector in each recipient country for environmental and food safety regulatory reviews. Conversely, donations for mixed public/private use within the same country allow the public sector to piggyback on the private sector regulatory reviews. The private donor benefits from an increased impetus for a timely review process, as well as from general good will.

*Corresponding author 


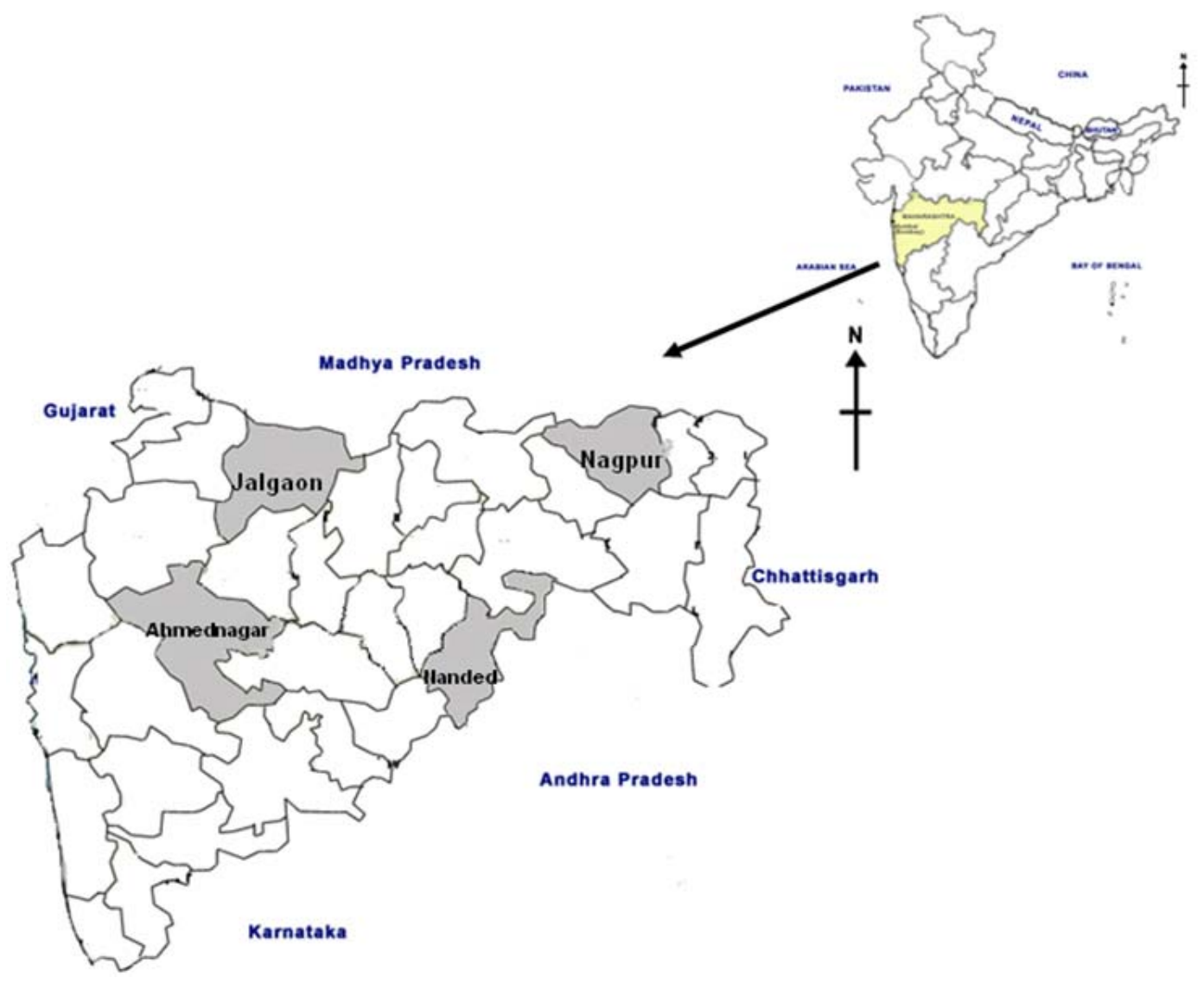

Appendix 1. Map of the study area.

Public/private use donations go back at least to the 1990s when Monsanto donated a virus resistant technology for potatoes for use in Mexico (Salamini, 1999). The issue for the donating firm is always how to separate markets sufficiently so that the donated technology does not unduly cannibalize the target market - what Lybbert calls the 'displacement effect' (Lybbert, 2002). In the Mexican potato case, the solution was to donate the technology only for varieties used locally (in contrast to those commercial growers for say french fries would use). However, the cost of transforming and propagating potatoes meant this project was not economically viable.

Here, we examine ex ante another approach to enable the co-existence of a donated and marketed technology. The case applies to the use of a Bt (Bacillus thuringiensis) construct for controlling shoot and fruit borers in eggplants (Eggplant shoot and fruit borer-ESFB) in India. Eggplant is an important non-seasonal vegetable produced throughout India. Yet ESFB reduce yields by up to 70 percent by destroying either the plant or the fruits (Dhandapani et al. 2003). The particular arrangement to be evaluated here provides for Mahyco (an Indian seed company partly owned by Monsanto) to donate the technology to public institutions for use in open pollinated seeds while selling $B t$ hybrid seeds with a premium (http://www.bic.searca.org/news/2005/nov/phi/27b.html). In this paper we focus only on whether the existence of lower cost Bt open pollinated variety (OPV) competitor product will cannibalize the Bt hybrid market to the extent that the donor has no incentive to donate the technology, thereby posing a threat to the feasibility of the donation project. The economic question then is if the willingness of farmers to pay a sufficient premium for hybrid Bt seed when open pollinated varieties with the same $\mathrm{Bt}$ gene construct are available without a surcharge compensate the firm adequately to ensure the feasibility of the project. Here we examine the conditions under which that apply, and project when similar arrangements will be viable/ feasible in other countries and for other crops.

\section{Data Collection}

The research team comprised of two enumerators and one of the authors conducted a farm-level survey using structured questionnaires in Maharashtra, India, in 20042005[i]. The districts included in the study were: Jalgaon, Nagpur, Ahmad Nagar, and Nanded (map of the study area is presented in Appendix 1). These districts were chosen to 
represent the four major geographical zones (Marathwada, Vidarbha, Khandesh, and Western Maharashtra) of the state, and to collect information on different market segments of the eggplant. Farmers were selected randomly from lists of eggplant farmers or from lists of all farmers provided by village administrative authorities. The sample included 249 eggplant farmers and 41-non eggplant vegetable farmers. In addition, general information on the sample villages was collected from village administrative authorities. The research team used separate questionnaires to interview eggplant growers, non-eggplant growers and village administrative authorities. In addition to collecting costs and production data, eggplant farmers were asked to state their willingness to purchase $B t$ seeds under different price and performance scenarios[ii]. Many area farmers were familiar with $B t$ cotton, so questions were not unduly abstract for them.

\section{Field trials of Bt eggplant}

The Bt hybrid eggplant developed by Mahyco contains a gene, Cry1Ac, obtained from Bacillus thuringiensis, which produces a protein toxic to ESFB. The $B t$ construct has been donated to selected Indian public institutions for development of OPV varieties only, and at public expense. The first round of field trials for Bt hybrid eggplant was conducted in 11 locations, covering seven states (Andhra Pradesh, Tamil Nadu, Karnataka, Maharashtra, Madhya Pradesh, Punjab, and Uttar Pradesh) in India, during 20042005. Five Mahyco hybrids suitable for different agroclimatic conditions were evaluated in these trials. Field trials of three additional hybrids were conducted in six locations in the year 2005-2006. In each trial location, Bt hybrid was grown next to non-Bt counter parts, and other conventional checks (popular OPV, competitor's hybrid). Each trial location consisted of 20 plots with five replications of each of the four types (Bt hybrid, non-Bt counterpart, competitor's hybrid, and popular OPV). The net plot size was $16.2 \mathrm{~m}^{2}$, thus the five replications resulted in an area of $81 \mathrm{~m}^{2}$ for each type. The data from field trials were extrapolated on per hectare basis for further analysis.

Field trial data of $B t$ hybrid eggplant provided by Mahyco indicate a $52 \%$ decrease in insecticides use, and a 39\% decrease in the number of insecticide-sprayings compared to non-Bt counterparts. The average yield from Bt trial

Table 1. Farmer and farm characteristics of surveyed hybrid and OPV growers.

\begin{tabular}{|c|c|c|}
\hline Category & Hybrid growers & OPV growers \\
\hline Area under eggplant(hectares) & $0.48(0.5)^{\star \star}$ & $0.28(0.21)$ \\
\hline Total land area owned (hectares) & $4.3(0.33)^{\star}$ & $3.6(2.6)$ \\
\hline Family size (number) & $7.3(5)$ & $6.6(3.4)$ \\
\hline Age of the family head (years) & $44.4(11.6)^{\star \star}$ & $48.5(12.8)$ \\
\hline Number of years of schooling & $7.7(4.4)$ & $7.2(4.8)$ \\
\hline Access to banks (1- if good access, 0 otherwise) & $0.87(0.34)^{\star \star}$ & $0.76(.43)$ \\
\hline Market size ('000) & $2237(4138)^{\star \star}$ & $7.7(9)$ \\
\hline Number of irrigations per season & $28.7(25)^{\star \star}$ & $17.1(11.6)$ \\
\hline District 1 (1 if Jalgaon, 0 otherwise) & $0.09(0.29)^{\star \star}$ & $0.54(0.50)$ \\
\hline District 2 (1 if Nagpur, 0 otherwise) & $0.28(0.45)$ & $0.28(0.45)$ \\
\hline District 3 (1 if Ahmad Nagar, 0 otherwise) & $0.4(0.5)^{\star \star}$ & 0 \\
\hline District 4 (1 if Nanded, 0 otherwise) & $0.24(0.43)$ & $0.18(0.39)$ \\
\hline Number of observations & 156 & 93 \\
\hline
\end{tabular}

Standard deviations are given in the parentheses. Market size indicates the population size of the market in which eggplant is sold. The symbols **,* denote that the mean values are statistically different between the two groups at 5 , and $15 \%$ levels respectively. 
plots was $117 \%$ higher than that of non-Bt counterparts[iii].

\section{METHODS}

We use partial budget analysis to estimate the expected returns from adopting the two variants of Bt technology (i.e. Bt hybrid and Bt OPV) for hybrid and OPV farmers. Production costs other than pesticide savings and seed costs are assumed to be identical to non- $B t$ seed. Non-hybrid $B t$ benefits are assumed to be proportionally similar to those for hybrids.

According to the scientists working in the project similar benefits could be expected for Bt OPV and Bt hybrid, as the $\mathrm{Bt}$ construct used is same. However, the proportionate benefits will be based on the current performances of hybrid and OPV eggplants. As with all field trial data, commercial performance may under-perform field trials. Due to annual and unpredictable variations in pest loads, the economic benefits from adopting $B t$ technology will be higher in high pest infested areas and years, while leading to lower gains when pest pressures are low. In recognition of the lower yield effects and pesticide savings achievable in commercial operations, a modest yield increase of $48 \%$, and limited savings of $40 \%$ for pesticide expenses are used in our analysis of estimated returns from adopting $\mathrm{Bt}$ eggplant[iv].

The price increase of the Bt seed, which is related to the premium paid to the gene's patent owner (Monsanto) and the developer of the new variety (Mahyco), is difficult to estimate. In the United States, markups on transgenic varieties follow two strategies: a premium paid above the price of seeds of the variety, and a technology fee paid by the planted acre (Hareau et al. 2005). The seed premium might be estimated based on per acre cost reduction in pesticides use with the assumption that the seed premium cannot be higher than the cost reductions achieved due to the use of Bt technology (Couvillion et al. 2000).

We estimated farmers' willingness to pay (WTP) for Bt eggplant using data from the farm-level survey. Given that most of the surveyed farmers knew about Bt cotton in India, and during the survey farmers were told about the potential benefits and risks associated with the technology, using the estimated WTP as a proxy for seed markup (including seed premium and technology fee) for the technology not yet commercialized is reasonable. The procedure used to estimate the WTP for Bt hybrid seed is detailed below.

A modified version of double bounded dichotomous choice contingent valuation (CV) approach was used to elicit the WTP for potential adopters of Bt hybrid eggplant. The econometric procedure used to reflect the nature of the dependent variable (WTP) was constructed from the relevant survey question. Since the observed variable $\mathrm{Y}$ has

Table 2. The estimated returns for hybrid growers from adopting Bt technology.

\begin{tabular}{|c|c|c|c|}
\hline S.NO & Cost/return components & $\begin{array}{c}\text { Hybrid } \rightarrow \\
\text { Bt hybrid (Rs/ha) }\end{array}$ & $\begin{array}{c}\text { Hybrid } \rightarrow \\
\text { Bt OPV(Rs/ha) }\end{array}$ \\
\hline i & Pesticide savings-40\% & 13076 & 25380 \\
\hline ii & Yield benefits-48\% & 47086 & 584 \\
\hline iii & Sub total of returns (i+ii) & 60162 & 25964 \\
\hline iv & Seed_prices & & $1163^{\star \star \star}$ \\
\hline & 1 & $12004^{\star}$ & 0 \\
\hline V & 2 & $6625^{\star \star}$ & \\
\hline & Net returns & & 24801 \\
\hline & 1 (iii-iv1) & 48158 & 25964 \\
\hline
\end{tabular}

The values in the third column represent the estimated returns of switching from hybrid to $\mathrm{Bt}$ hybrid. The values in fourth column represent the estimated returns of switching from hybrid to Bt OPV. The symbols *, and ** denote that seed prices are Rs 540/10g, and Rs 298/10g respectively for Bt hybrid. We used a seed rate of $222 \mathrm{~g} / \mathrm{ha}$ for Bt hybrid. The symbols ${ }^{\star \star \star}$, and **** denote that seed prices are Rs $62 / 50 \mathrm{~g}$, and zero respectively for Bt OPV. We used a seed rate of $939 \mathrm{~g} / \mathrm{ha}$ for Bt OPV. 
an ordered response (willingness to adopt Bt hybrid or not, at two bids), there are two possible procedures that could be exploited here. A standard ordered probit model could be used, as this captures the ordinal nature of the dependent variable (Wooldridge, 2002). However, it assumes that the threshold values delineating the different categories are unknown and the interval-coded nature of the data would thus be ignored in estimation. The second procedure which we used in this analysis explicitly takes into account the values of known thresholds governing the intervals (Wooldridge, 2002). Specifically, we are interested in estimating the WTP for Bt hybrid seed, i.e. $\mathrm{E}\left(\mathrm{Y}^{*} / \mathrm{X}\right)$, where $\mathrm{Y}^{*}$ is the willingness to pay for Bt hybrid seeds. Hence, the potential adopters of the Bt hybrid technology in the sample are divided into the following three categories based on their responses to WTP question,

1. $\operatorname{Prob}\left(\mathrm{Y}^{*} \geq R s 400\right)=\mathrm{P}\left(\mathrm{Y}^{*} \geq 400 / \mathrm{X}\right)=\mathrm{I}^{\mathrm{Y}}$

$=[1-\Phi(400-\mathrm{X} \beta) / \sigma]$ where $\Phi()$ denotes the standard normal distribution

Similarly

2. $\operatorname{Prob}\left(\right.$ Pbid $\left.\leq Y^{*}<R s 400\right)=\mathrm{I}^{\mathrm{NY}}=$

$\left.\Phi\left(\frac{400-\mathrm{X} \beta}{\sigma}\right)-\Phi\left(\frac{P b i d-\mathrm{X} \beta}{\sigma}\right)\right)$
3. $\operatorname{Prob}\left(\mathrm{Y}^{*}<\right.$ Pbid $)=\mathrm{I}^{\mathrm{NN}}=\Phi\left(\frac{\text { Pbid }-\mathrm{X} \beta}{\sigma}\right)$

Where $I^{\mathrm{Y}}$ (yes), $\mathrm{I}^{\mathrm{NY}}$ (No, Yes), $\mathrm{I}^{\mathrm{NN}}$ (No, No) are binary indicator choice variables for each farmer based on the above three categories. In addition to the interval - coded data, some responses are point data - either zero or some positive values. In order to make use of all these information, interval regression model is used for estimating the mean WTP. The likelihood for the interval regression including both interval-coded and point data is

$$
\begin{aligned}
& L=-0.5 \sum\left\{\left(\left(\mathrm{Y}_{j}-\mathrm{X} \beta\right) / \sigma^{2}\right)+\log 2 \pi \sigma^{2}\right\}+\sum_{j \in R} \log \left\{1-\Phi\left(\left(\mathrm{Y}_{R j}-\mathrm{X} \beta\right) / \sigma\right)\right\}+ \\
& \sum_{j \in I} \log \left\{\left(\left(\mathrm{Y}_{400 j}-\mathrm{X} \beta\right) / \sigma\right)-\Phi\left(\left(\mathrm{Y}_{b i d j}-\mathrm{X} \beta\right) / \sigma\right)\right\}+\sum_{j \in L} \log \Phi\left(\left(\mathrm{Y}_{L j}-\mathrm{X} \beta\right) / \sigma\right)
\end{aligned}
$$

where observations $\mathrm{j} \in C$ are point data; observations $\mathrm{j} \in R$ are right-censored; observations $\mathrm{j} \in I$ are intervalcoded data; and observations $\mathrm{j} \in L$ are left censored. $\mathrm{Y}_{\text {bidj }}$ is the one step-down hypothetical bid price, $\mathrm{Y}_{R j}$ is the right censored WTP, $Y_{L j}$ is the left censored WTP, and $Y_{j}$ is the point data. The mean WTP can be obtained using the estimated parameters from equation (4) at the mean level of the explanatory variables. Following Wooldridge (2002), the formula for mean WTP of Bt hybrid is $\mathrm{E}\left(\mathrm{Y}^{*} / \mathrm{X}\right)=$ $\overline{\mathrm{X}} \beta$. Since an open-ended $\mathrm{CV}$ format was used for

Table 3. Estimated benefits for OPV growers from adopting Bt OPV and Bt hybrid technologies.

\begin{tabular}{|c|c|c|c|}
\hline S.NO & Cost/return components & Bt OPV(Rs/ha) & Bt hybrid (Rs/ha) \\
\hline i & Pesticide savings- 40\% & 5165 & -7405 \\
\hline ii & Yield benefits- 48\% & 32115 & 78243 \\
\hline iii & Sub total of returns (i+ii) & 37280 & 70838 \\
\hline iv & Seed prices & & \\
\hline & 1 & $1163^{\star}$ & $12004^{\star *}$ \\
& 2 & 0 & $6625^{\star \star *}$ \\
\hline v & Net returns & 36117 & 58384 \\
\hline & 1(iii-iv1) & 37280 & 64213 \\
\hline
\end{tabular}

*Seed price is taken as Rs $62 / 50 \mathrm{~g} .{ }^{* \star}$ Seed price is taken as Rs 540/10 g. *** Seed price is taken as Rs 298/10 $\mathrm{g}$. 
eliciting the WTP for Bt OPV, the average of the responses was estimated and used in the analysis.

\section{RESULTS}

\section{Current practices in eggplant production}

About $60 \%$ of the eggplant growers in the sample use hybrids, purchasing seeds annually at an average price of Rs 75/10 g (1 US \$ was equivalent to 44.5 Indian Rupees at the time of survey). Other farmers grow open pollinated varieties (OPVs), which are produced by natural pollination, and use farm-saved seeds for succeeding years. Since our sample includes different groups of eggplant farmers in the different agro-climatic conditions in the survey districts our sample is representative of the state. The average market price of OPV seeds is Rs $3 / 10 \mathrm{~g}$. OPV seeds are marketed in $50 \mathrm{~g}$ packets compared to $10 \mathrm{~g}$ packets for hybrid seeds.

Overall, our data suggest that hybrid and OPV growers follow quite different production systems. Hybrid growers use more purchased inputs with higher yields compared to OPV growers. For example, in our survey, hybrid growers spent Rs 32,692/ha on pesticides compared to Rs 12,913/ha for OPV growers. The average yield of hybrid growers (16.8 metric tons/ha) was $47 \%$ higher than that of OPV growers (11.4 metric tons /ha). Since the average price of hybrid and OPV eggplant fruits are similar, the high variable costs (mainly on pesticides) incurred narrows the profit range net of variable costs between hybrid and OPV growers.

For a better insight into the two groups of eggplant producers, Table 1 presents the farm and farmer characteristics of hybrid and OPV growers included in our survey. Our results suggest that hybrid farmers have larger farms, better access to banks, and larger households compared to OPV growers. Moreover, hybrid farmers rely more heavily on irrigation, in part because they produce crops during the kharif (monsoon) as well as the summer (dry) seasons[v]. Irrigation is a loss/ risk-reducing technology relatively more important for high than for low input crops. Hence, better access to irrigation is a notable distinction between the two producing groups.Our analysis does not include land costs which are unavailable. Typically, land situated closer to urban areas (which in our study applies to the hybrid growers) is higher valued than land in more remote locations. However, we have data on market size and use it as proxy for land value (i.e. population of the market in which the eggplant is marketed. For example, if it is a village market, population of the village is taken as the market size). Overall, current hybrid growers have better access to larger markets implying higher land value or cost. Hence they may invest in $\mathrm{Bt}$ hybrid technology to reduce the land cost/unit of output. Resource-limited farmers located in marginal areas may be further restrained by limited access to credit needed for hybrid production as well as lacking the management requirements of a more resource intensive technology, as

Table 4. Sensitivity analysis of the expected returns for hybrid growers under different scenarios of Bt adoption with $25 \%$ reduction in the commodity price.

\begin{tabular}{|c|c|c|c|}
\hline S.NO & Cost/return components & $\begin{array}{c}\text { Hybrid to } \\
\text { Bt hybrid (Rs/ha) }\end{array}$ & $\begin{array}{c}\text { Hybrid to } \\
\text { Bt OPV(Rs/ha) }\end{array}$ \\
\hline i & Pesticide savings at 40\% & 13076 & 25380 \\
\hline ii & Yield benefits at 48\% & 35295 & 438 \\
\hline iii & Sub total (i+ii) & 48371 & 25818 \\
\hline iv & Seed prices & & -244 \\
\hline & 1 & $12004^{*}$ & 0 \\
\hline v & Net returns (iii-iv) & $6625^{\star *}$ & 25062 \\
\hline & 1 & & 36367 \\
\hline
\end{tabular}

The commodity price was taken as the four year average of the national level prices of eggplant during 2000-2004. The sensitivity analysis captures a change in output price from Rs 5,839/metric tons to Rs 4,379/metric tons. The price data was available at http://agmarknet.nic.in/. Symbols *, and ${ }^{* *}$ denote the seed prices at Rs 540/10g and Rs 298/10g respectively. While switching from hybrid to Bt OPV, hybrid growers save Rs 244/ha. 
well as possibly having limited market access. Determining which combination of these factors is more pertinent in inhibiting the adoption of hybrid technology by resourcepoor farmers exceeds the scope of our analysis.

\section{Potential benefits from Bt eggplant and feasibility of humanitarian donation}

Table 2 presents the estimated additional benefits and costs of adopting $B t$ technology for hybrid growers under different projected Bt-seed prices. The seed prices used in Table 2 were derived from estimated values of farmers' willingness to pay (WTP) for the Bt technology. The average estimated WTP for Bt hybrid seed was Rs 298/10 g packet for the full sample, which is more than four times the conventional hybrid seed price. Results from our analysis showed that the company profit decreases with a seed price (estimated WTP) above Rs 540/10g packet due to decrease in the projected adoption rate. Hence, we included Rs 540/10g packet as the upper level of Bt hybrid seed price in our analysis. Results from our analysis (Table 2) show hybrid growers gain more from adopting Bt hybrid varieties than from low priced Bt OPVs, due mainly to the yield effect of hybrid technology. Hence there is no incentive for the hybrid growers to shift to low priced $\mathrm{Bt}$ OPVs when they become available and suggests the feasibility of the donation project for the technology owner.

We also estimated the additional benefits and returns for OPV growers from adopting Bt OPV and Bt hybrid varieties (Table 3). Our analysis suggests that resourcelimited farmers could gain more from adopting Bt hybrid mainly because of the expected yield benefits. Indeed, the analysis indicates that current OPV growers could earn a higher return over variable costs by adopting Bt hybrids, which raises the question of what inhibits change. In an earlier work Kolady and Lesser (2006) used standard economic techniques to project the adoption of Bt eggplant in both its hybrid and OPV variants under different scenarios of productivity and seed prices. The authors reported that hybrid farmers have higher probability to adopt Bt hybrid while OPV farmers have higher probability to adopt Bt OPV. The results reported in Kolady and Lesser (2006) also showed that with the introduction of low priced Bt OPV there will be a reduction in the expected adoption rate of Bt hybrid (from 46\% to 39\%). However, most of the early adopters of Bt hybrid are more likely to continue with Bt hybrid eggplant.

However, increased total production due to the $B t$ technology may lower the market price of eggplant, making Bt hybrid less profitable. To analyze the robustness of the estimated returns in this study, a sensitivity analysis was conducted assuming a $25 \%$ reduction in the average market price, but keeping all other values as in Table 2 (i.e. for hybrid growers). The results are presented in Table 4. Our analysis suggests that although a reduction in the commodity price narrows the benefits between Bt hybrid and Bt OPV for hybrid growers, adopters of Bt hybrid are likely to gain more than those adopting Bt OPVs. Hence what is evident from our current analysis is that differences in the farm and farmer characteristics of hybrid and OPV growers imply that Bt hybrid and Bt OPV target different groups of farmers, and segmentation of the market is possible. Further, the productive merit of hybrid technology enables the co-existence of $\mathrm{Bt}$ hybrid and Bt OPVs by avoiding farmers' switch to low priced Bt OPVs from $\mathrm{Bt}$ hybrids. In the long run, the private donor benefits from an increased impetus for a timely review process, as well as from general good will.

\section{CONCLUDING REMARKS}

Overall, our data and analysis suggest that due to the differences in the production characteristics of hybrid and OPV growers, hybrid growers have a willingness to pay more for Bt hybrid and gain more from adopting Bt hybrid varieties than from adopting Bt OPVs. Thus, the donation plan adopted by Mahyco appears to allow for low cost access by small farmers while being commercially viable in the sense of allowing Mahyco to maximize revenues according to farmers' willingness to pay more for higher productivity. Whether that price will allow for a profitable venture requires firm cost data beyond our access to determine. Conversely, the success of the donation plan depends heavily on the seed price charged for Bt hybrid by the private company. While our analysis suggests Mahyco can charge the estimated maximum WTP in our study as price without causing a shift from Bt hybrids to Bt OPVs, it is possible that the actual price set could cause more switching than is projected here.

The attribute which allows for the simultaneous existence of a premium price and no cost technology for eggplant growers (i.e. the feasibility of the donation project) in India is the existence of two distinct levels of production technology, one high input/yield, one low. A key condition for those two management systems being viable for the same crop is differences in access to irrigation. Related factors include land cost, itself associated with proximity to major markets in a country with a slow and costly transportation system. Many developing countries share the characteristics of limited access to irrigation, along with few major markets and high cost internal transportation systems, leading to a premium price for land closest to major markets. Thus, the 'Mahyco model' would seem to be viable/feasible for humanitarian donations of agbiotechnologies with the following provisos:

- Irrigation is required at least periodically as a riskreducing input.

- Perishable crops are most affected by transport costs and delays so that the viability of the approach for nonperishable staples must be evaluated further,

- Transport costs are not subsidized or the cost effects of transport distance otherwise mitigated so that land prices are less affected by market proximity, 
- Some farmers at least have access to short term capital allowing a greater investment in planting costs,

- The productivity of the premium priced seed (in this example $B t$ hybrids) is sufficiently greater than the alternative to justify a substantial price premium. For example, $B t$ cotton seed in India has been priced at four times the conventional alternative (subsequently reduced to three times by the state governments such as Andhra Pradesh's), and;

- An earlier market entry by the premium-priced variant would seem to confer additional security for its market, but that factor was not specifically examined here.

Clearly, alternative approaches will be needed for other crops and conditions, but this preliminary analysis does indicate one viable approach is being implemented.

\section{ACKNOWLEDGMENTS}

Authors acknowledge, Dr. Usha Barwale of Mahyco for sharing the field trial data of Bt hybrid eggplant with us.

\section{REFERENCES}

BYERLEE, Derek and FISCHER, Ken. Accessing modern science: policy and institutional options for agricultural biotechnology in developing countries. World Development, June 2002, vol. 30, no. 6, p. 931-948.

COUVILLION, Warren C.; KARI, Fatimah; HUDSON, Darren and ALLEN, Albert. A preliminary economic assessment of roundup ready soybeans in Mississippi. Research Report 5, Mississippi State University, May 2000, p. 1-11.

DHANDAPANI, N.; SHELKAR, U.R. and MURUGAN, M. Bio-intensive pest management (BIPM) in major vegetable crops: an Indian perspective. Journal of Food, Agriculture and Environment, 2003, vol. 1, no. 2, p. 330339.

FAO. The state of food and agriculture 2003-2004. Agricultural Biotechnology: Meeting the needs of the poor. Food and Agriculture Organization of the United Nations, Rome, 2004. 208 p.

HAREAU, G.G.; NORTON, G.W.; MILLS, B.F. and PETERSON, E. Potential benefits of transgenic rice in Asia: a general equilibrium analysis. Quarterly Journal of International Agriculture, 2005, vol. 44, no. 3, p. 229-246.

KOLADY, Deepthi Elizabeth and LESSER, William. Who adopts what kind of technologies? The case of Bt eggplant in India. AgBioForum [online]. 2006, vol. 9, no. 2, p. 94103 [January 20 2007]. Available from Internet: http://agbioforum.org/v9n2/v9n2a04-kolady.htm. ISSN 1522-936X.
LYBBERT, Travis J. Technology transfer for humanitarian use: economic issues and market segmentation approaches. IP Strategy Today [online]. 2002, vol. 5, p. 17-24 [January 25 2007]. Available from Internet: http://www.biodevelopments.org/ip/ipst5.pdf.ISSN 15346447.

SALAMINI, Francesco. North-South Innovation Transfer. Nature Biotechnology, March 1999, vol. 17, p. BV11BV12.

WOOLDRIDGE, Jeffrey M. Econometric analysis of cross section and panel data. MIT Press Cambridge, Mass, 2002. 752 p. ISBN 0-262-23219-7.

[i] A pilot survey was conducted two months prior to the survey to train the enumerators and to check the farmers' level of understanding of the survey questions. Based on the feedback received from the survey pretesting, necessary revisions were made in the original questionnaires.

[ii] In our survey, for the willingness to pay (WTP) question for Bt hybrid, the first bid offered was Rs 400/10 g packet, if the response was "no" from the farmer, a lower bid was offered .The lower bids offered were: Rs 350, Rs 300 , Rs 250 , Rs 200, and Rs 150 each for a $10 \mathrm{~g}$ packet. The bid ranges were chosen to cover what we perceived to be a likely range of retail prices, and WTP for Bt hybrid seeds. During the pre-testing of the survey, we identified farmers' difficulties in responding to a double-bounded CV framework for Bt OPV. This may be due to the fact that OPV seeds are marketed at a cheaper price and that farmers do not replace seeds of open pollinated varieties annually. Hence, an open-ended CV format where farmers were requested to state their WTP for Bt OPV eggplant was used.

[iii] The details of the field trials of GE eggplant can be found at (http://www.envfor.nic.in/divisions/csurv/geac/information_brinjal.htm).

[iv] These vales were selected comparing the field trial results of $\mathrm{Bt}$ eggplant with that of commercial performance of eggplant and Bt cotton in India.

[v] Kharif is the South-West monsoon season in India. 